\title{
The Places and Tools of Execution
}

\begin{abstract}
The materiality of gallows' sites and the apparatus of execution had their own magical and medical afterlife, inextricably linked with, yet ultimately independent of, the executed criminal. This chapter includes discussion on European gallows traditions, English legends of providential strangulation, and the trade in and lore of the gallows mandrake. It then focuses on the trade in hanging ropes in Europe and America, and the relationship between mementos and magical talismans.
\end{abstract}

Keywords Gallows · Providence $\cdot$ Mandrake $\cdot$ Hanging rope $\cdot$ Talisman

We move now from matters concerning the identity and potency of criminal bodies to their post-mortem relationship with the immediate physical environment where their last sentient moments were extinguished and witnessed. The materiality of gallows sites and the apparatus of execution have their own magical and medical afterlife, inextricably linked with, yet ultimately independent of, the executed criminal.

During the eighteenth and nineteenth centuries, execution sites across Western Europe were increasingly situated in fixed locations, with those sentenced for capital offences being condemned to die 'at the usual place'. There had always been a mix of urban and rural gallows, of course, but the process of state-building led to centralised control over

(C) The Author(s) 2017

O. Davies and F. Matteoni, Executing Magic in the Modern Era, 53

Palgrave Historical Studies in the Criminal Corpse and its Afterlife, DOI 10.1007/978-3-319-59519-1_4 
the act of execution as punishment and spectacle. It also led to the closer spatial association of gallows with judicial institutions, such as jails, rather than with the communities in which the crimes took place or where the condemned criminals lived. ${ }^{1}$ There are, of course, exceptions and anomalies. In England, between 1720 and 1830, nearly 200 people were hanged on specially erected scaffolds near the scene of their crime, quite often on remote hilltops. ${ }^{2}$ Their purpose was to act as exceptional spectacular warnings - particularly to rioters-and to spread the message of law and order in often isolated rural areas.

There was also a general shift away from permanent gallows in the modern era. The famous Tyburn gallows in London was replaced in 1759 by a portable scaffold. In Lower Austria, a law of 1786 ordered the removal of a series of permanent, monumental stone gallows that had been constructed in the seventeenth and early eighteenth centuries, usually on natural elevations near major roads. ${ }^{3}$ In 1808, a German Police chief complained to his superiors in Munich that these 'misshapen monuments, gallows, and scaffolds still insult the bright eye of the wanderer and carry his mind involuntarily back to the days when the hangman was one of the state's busiest servants'. He continued that 'it is incompatible with the principles of the present to have the gallows as the first thing one sees on approaching every important place'. Three years later, the kingdom of Württemberg dismantled its permanent gallows and ravenstones, and other German states soon followed suit if they had not done so already. ${ }^{4}$ The disused gallows that remained in the landscape shifted from being landmarks of state justice to being antiquarian curiosities. A visitor to the Swedish town of Visby in the early nineteenth century remarked, for instance, upon the 'relic' of the town's disused permanent gallows, 'yet remaining, formed of the pillars placed in a triangular position; a beam serving as the gallows passes from pillar to pillar; below is a well, into which the bodies of the unhappy sufferers were either thrown or suffered to fall piecemeal'. 5

The terms gibbet and gallows are often confused, or used indiscriminately for both execution and post-mortem sites. In some cases, such as with English crime scene executions, the same post was used for both execution and hanging in chains, thereby leaving a much longer physical reminder of both judicial acts. In rural Southern Netherlands, execution gallows, post-mortem display and eventual burial were usually on the same spot, as distinct from urban areas where executions took place in the town centre, with the corpse then being taken outside the town 
for display. As Sarah Tarlow explores, gibbets remained striking features in the landscapes for decades: 'The presence of a gibbet could change the experience of a local landscape for a long time after its erection even to the present day. ... giving emotional impact to local journeys.' In the eighteenth century, gibbets were still sometimes located at places that might already have their own folklore, such as on old prehistoric barrows, which were usually sited on hilltops and ridges, or crossroads or parish boundaries where medieval and early modern executions had long taken place. ${ }^{6}$

So, a few decades before public execution was abolished across much of Europe, the sight and site of the gallows had become largely fleeting urban fixtures. Yet across the countryside, the legacy of centuries of executions remained in place names, such as Hangman's Field and Gallows Hill-Galgenberg in German. Sometimes place names provide the only evidence of the location of temporary or one-off execution and gibbeting sites over the centuries. Some can be dated in the archives as having medieval and early modern origin, but other names record more recent events, such as Gibbet Hill Lane at Scrooby, which memorialises the 1779 gibbeting of John Spencer. ${ }^{7}$ More to the point, we find numerous stories, beliefs and legends relating to the ghosts of the executed haunting the locations long after the gallows or the gibbet had been taken down. Nearly two centuries on from the gibbeting of a man on Maundown Hill, Wiveliscombe, Somerset, in 1727, for murdering his mother, Thomazin Tudball, people still told stories of his frightening spiritual presence as they drew near the isolated spot. Horses became terrified as they approached where the gibbet used to stand. ${ }^{8}$ Accounts of horses sensing and fearing old gallows and gibbet spots were quite widespread. It was recorded in the early twentieth century, for instance, that the reason horses feared crossing Pilfer Bridge, near Normanby, Lincolnshire, was because of an old long-gone gibbet nearby, memorialised in the locality by a property called Gibbet Post House. ${ }^{9}$

Writing in the 1890s, the observant Cumbrian antiquarian, Henry Swainson Cowper, mentioned the folklore surrounding Gibbet Moss, near the Lake District town of Hawkshead. The poet, Wordsworth, recalled seeing the gibbet post still standing there as a boy. As recorded in the parish register, it was that which bore the body of Thomas Lancaster, who was executed in 1672 for poisoning his family. He was hanged in front of his home and then his corpse was taken away to be hanged in chains on the spot that came to be known later as Gibbet 
Moss. ${ }^{10}$ As Cowper noted, 'The simplest form of haunt is simply that in which a particular place bears a bad reputation without there being attached to it any distinct apparition.' Other than its bad reputation and name, Cowper thought 'probably there are now many people who are unaware that a gibbet ever stood here.' This seems to be the case for most haunted gibbets recorded in the late nineteenth and early twentieth centuries. The post long gone, the name of the executed usually forgotten in local lore, no one could visualise what he might look like: but there remained an unsettling presence.

The gallows and gibbet from which swung the corpse of Thomas Colley, executed for the drowning of a suspected witch in 1751, were haunted by a black dog. Colley was tried in Hertford, but he was executed and gibbeted thirty miles away at Gubblecote Cross, which was a crossroads near where the fatal swimming occurred at Marston Mere. The execution and gibbeting did not take place at the crime scene, because the locals successfully petitioned against it. ${ }^{11}$ Just over a century later, the local schoolmaster claimed to have seen the demonic dog when returning home one night in his gig. 'When we came near the spot, where a portion of the gibbet had lately stood, we saw on the bank of the roadside ... a flame of fire as large as a man's hat ... I then saw an immense black dog lying on the road just in front of our horse ... The dog was the strangest looking creature I ever beheld.' ${ }^{12}$ The association of animal spirits with humans who died a violent or tragic death, such as the executed and suicides, was widespread in folk tradition. ${ }^{13}$ We will return to this in the next chapter.

\section{Providential Gallows}

Dotted across the English landscape are some two dozen or so 'hangman's stones' that also served as symbolic warnings to would-be thieves. These are usually Bronze Age standing stones, wayside crosses, or boundary and milestones. Writing in 1803, the Gloucestershire antiquarian, Thomas Rudge, wrote of one such example in the county, 'An ancient rude stone, about four feet high, commonly called Hangman's stone, with a vulgar tradition annexed to it, not worth recording, stands in the road, about two miles from Cirencester, and is now converted into a mile-stone.' The vulgar tradition referred to was related by an earlier, and less pompous, Gloucester antiquarian, who explained that it was called Hangman's Stone because cit is said, a fellow resting a sheep 
thereon, (which he had stolen, and tied its legs together for the convenience of carrying it) was there strangled, by the animal's getting its legs round his neck in struggling'. ${ }^{14}$ The same story of the asphyxiation of a sheep thief resting upon a stone with his ill-gotten carcass was attributed to most of the other hangman's stones, though a mid-nineteenthcentury poem records the similar fate of a Leicestershire deer poacher named John of Oxley:

There was Oxley on one side the stone,

On the other the down-hanging deer;

The burden had slipp'd, and his neck it had nipped;

He was hanged by his prize - all was clear!

The gallows still stands upon Shepeshed high lands,

As a mark for the Poacher to own,

How the wicked will get within their own net;

And 'tis still cal'd 'THE GREY HANGMAN'S STONE.'15

The fact that the same legend was attributed to different stones around the country was remarked upon in the late nineteenth century, and was given further attention in the 1920s by the influential archaeologist, O.G.S. Crawford, who compiled a brief gazetteer of sites. ${ }^{16}$ Crawford mused on the possible medieval origin of the hangman's stone, being so named from being parish or hundred boundary stones near a gibbet or execution site. The strangled sheep-thief story occurred much later to explain the name at a time when the execution site had long fallen out of public memory. Leslie Grinsell expanded on Crawford's list of sites, and, as far as it is possible to date, charted the chronology of the tradition. He found a couple of seventeenth-century references, but the rest dated from the mid-eighteenth century, the bulk being from the 1830s onwards. This dating only concerns the first literary references to the tradition of the various sites, of course, and does not necessarily reflect the age of the tradition in oral circulation.

How this 'migratory legend', as folklorists call it, became so widespread is difficult to pin down. The legend clearly relates to the fable, 'Poena sequens' or 'Punishment following', which appeared in 
sixteenth-century emblem books. A woodcut of a thief, being strangled by the tied legs of the pig carcass he has just stolen as he lies down to rest against a balustrade, is first depicted in Johannes Sambucus's Emblemata (Antwerp 1564). This was a book of images and associated moralistic epigrams that Sambucus intended 'to instruct and to delight'. ${ }^{17}$ It was soon translated into French, Dutch and English, and reprinted in other books of emblems. It first appears in English in Geoffrey Whitney's A Choice of Emblemes (1586), though in his version the thief is carrying a sack of meat stolen from a shambles.

The heavie loade, did weye so harde behind,

That whiles he slept, the weighte did stoppe his winde.

Which truelie shows, to them that doe offende,

Although a while, they scape theire just desertes,

Yet punishment, dothe as theire backs attende ...

And thoughe longe time, they doe escape the pikes,

Yet soone, or late, the Lorde in justice strikes. ${ }^{18}$

Did Sambucus take his story from a widespread European legend circulating in oral form? Or was it his literary invention that then, rather like some fairy tales, found its way from the page and into English oral folk tradition? A search through English ballads that might have borrowed Whitney's verse, and thereby disseminated the legend, did not turn up any examples.

Grinsell suggested that the apparent predominance of this English folk tradition from the mid-eighteenth century onwards was a reflection of the heightened concern over sheep stealing at the time. This was expressed in 1741 by An Act to render the Laws more effective for the preventing the stealing and destroying of Sheep. Despite the periodic concern, particularly when dearth and poor harvests led to apparent spikes in sheep theft, sheep stealing was considered a less heinous crime than horse theft and the punishment was often mitigated, particularly to transportation. Still, the deterrent effect was considered effective. In 1790, one judge expressed his satisfaction that since he 'ordered the execution of two sheep stealers 2 or 3 years ago the offence ... which had filled the calendar of every circuit for several years before that example was made has not once appeared'. ${ }^{19}$ 
The divine nature of the sheep thief's demise was suggested in one of the earliest versions of the legend associated with the Hanging Stone near Combe Martin, Devon. Referring to it, Thomas Fuller opined in the 1660s that 'it appeareth rather a Providence, than a Casualty; in the just execution of a Malefactor'. ${ }^{20}$ The providential aspect of John of Oxley's demise is certainly inferred in the poem above.

The death penalty for sheep stealing was repealed in 1832 , and it has been suggested the nineteenth-century ubiquity of this morality legend may have been a popular response to the ending of capital punishment for the offence, ${ }^{21}$ or it may just be a question of source bias. The hangman's stone tradition is best understood in the context of the broader and older tradition of divine justice or retribution being memorialised in the landscape, which was prevalent in folklore and ballads from the Reformation to the twentieth century. ${ }^{22}$ Another example is the legend associated with various Bronze Age stone circles and standing stones, that they were sinners petrified for dancing or playing games on the Sabbath. We see, in these traditions, popular manifestations of the state's attempt to imprint morality, justice and punishment on the landscape.

\section{The Gallows Mandrake}

In early modern and modern Europe, there was an oft-recorded belief that the mandrake, a plant with well-known magical associations, grew under the gallows. Ancient Greek writers, such as Hippocrates, noted the beneficial and toxic properties of the plant. The main source for its enduring magical associations, though, was an account of the plant written in the first century CE by the Roman-Jewish historian, Josephus. He told how the plant would not 'yield itself to be taken quietly, until either the urine of a woman, or blood, be poured on it'. Josephus was also the source of the method of pulling the mandrake out of the ground by tying a dog to the plant, the dog dying in the process. The association of the mandrake with the gallows is much later, though. It is first recorded in 1532 by the physician and botanist, Otto Brunfels (1488-1534), although he refers to the eleventh-century Persian physician, Avicenna, as a source, though no one has yet found it mentioned in Avicenna's work. What Brunfels stated as a current belief was that the mandrake, or alraun in German, grew from 'the sperm of a urinating thief' on the gallows. ${ }^{23}$ Over the next few years, the notion appeared in a few other German books. In 1534, Leonhard Fuchs referred to the 'land swindlers' 
who carved roots into human form, 'and they lie even more by saying that these roots have to be gathered under the gallows, with many ceremonies'. ${ }^{24}$ It is probably due to the influence of Brunfels work, though, that by the seventeenth century this notion, and variations upon it, were widespread in European medical literature. The French apothecary and herbalist, Laurent Catelan (c. 1568-1647), for instance, wrote a study of the mandrake, in which he discussed the generation of the mandrake from sperm released from criminals hanged or crushed on the wheel. Because of the frequency of hangings, he explained, the semen fell on ground that was rich in human fat, 'like that in a graveyard', which aided the fertilisation process. A woman's sperm (it was believed by Galenists that women also produced semen, though less potent) would not generate mandrake, however, 'even if she was strung up or crushed'. ${ }^{25}$ Small variations appear in the various seventeenth-century sources, such as that the mandrake was only generated from the fluids of a man unjustly hanged for theft, or who was a virgin, or a hereditary thief. ${ }^{26}$

While the medicinal properties of mandrake root were known widely enough in British herbal medicine, where it was used in particular to promote conception, the gallows mandrake tradition circulated little in English folk belief. ${ }^{27}$ John Gerard (1545-1612), in his influential Herball, castigated the 'ridiculous tales' regarding the plant, ruminating whether they were broadcast by 'old wives, or some runnagate Surgeons or physicke-mongers'. He was categorical that it was 'never or very seldome' found to grow naturally under the gallows. ${ }^{28}$ Likewise, Thomas Browne's dismissal of the notion in $\mathbf{1 6 8 5}$ as erroneous and injurious unto Philosophy' was a response to classical and continental sources, rather than native tradition. ${ }^{29}$

In Iceland, the mandrake was known as 'thieves root' and was thought to grow from the froth that dribbled from the mouth of the hanged. However, the gallows mandrake tradition was strongest in German lands, where it was known as the galgenmännlein or 'little gallows man', generated from the urine or semen leaking from the male corpse. The plant was also tellingly associated with crossroads where suicides were buried. While much of the evidence for the early modern tradition was regurgitated from a narrow pool of medical literary sources, it is clear that there was a popular trade in mandrakes purportedly taken from gibbet sites. The seventeenth-century German poet, Johann Rist, for instance, wrote of seeing an old carved mandrake placed in a little coffin with a cloth cover depicting a thief on the gallows. ${ }^{30}$ Paracelsus 
complained of the cheating vagabonds who traded in mandrakes, stating that mandrake roots did not grow in the form of humans; it was unscrupulous people who carved them thus. Brunfels also grumbled about those who cheated people by carving bryony roots and passing them off as mandrakes. In the late sixteenth century, Frantz Schmidt, the German executioner-physician and diarist, noted the activities of the thief and card sharp, Hans Meller, who traded in magical objects. He was convicted for coating yellow turnips in fat, sticking hair on the top and selling them as mandrakes. ${ }^{31}$

That some executioners were involved in the mandrake trade-selling fake products or otherwise-is evident from a letter written in 1575 by a burger of Leipsic to his brother in Riga. His brother was experiencing a series of misfortunes: his livestock was dying mysteriously, his beer had turned sour, and so had his relations with his wife.

I have, therefore, gone to those who understand such things to find what is needed, and have asked them why thou art so unlucky. They have told me that these evils proceed not from God, but from wicked people; and they know what will help thee. If though hast a mandrake and bring it into thy house, thou shalt have good fortune. So I have taken the pains, for thy sake, to go to those who have such things, and to our executioner have paid sixty-four thalers and a piece of gold drinkgelt to his servant, and this [mandrake], dear brother, I send thee.

Instructions were included about how the mandrake had to be left to rest for 3 days before being soaked in warm water, which was then to be sprinkled on the sills of the house and the sick animals. ${ }^{32}$

In eighteenth- and nineteenth-century France, interest in the mandrake was fuelled by the popular book of magic, Secrets merveilleux de la magie naturelle et cabalistique du Petit Albert. This included several pages on how to grow the mandragore or mandrake, and noted the belief that it brought good fortune to the possessor. The 'author' recalled meeting a rags-to-riches peasant, who told him how his own wealth was due to a gypsy woman who had told him how to grow a mandrake. This involved taking a bryony root, which had a human form, from the earth during the spring, when the moon was in an auspicious conjunction with Jupiter or Venus. The root then had to be trimmed and planted in a cemetery or in the grave of a dead man. Every day for a month, at sunrise, it had to be watered with the whey from cows' milk 
in which three bats had been drowned. After 1 month, the root was dug up and would be found to have taken on a human likeness. It then had to be dried in an oven with the plant vervain, and finally wrapped in a piece of the burial shroud of a dead person. ${ }^{33}$ So here we have an essential association with places of death, if not explicitly with the gallows. The Petit Albert also includes the most culturally influential recipe for creating the notorious Hand of Glory, in French known as the Main de Gloire, which is thought to be a corruption of the French for mandrake-mandragore. How the etymology arose is confused, but there is an obvious shared association with the gallows corpse.

Come the nineteenth century, it would seem that the gallows mandrake had become largely a matter of fiction rather than an object of the magic trade. The legend appealed to the imaginations of the Romantics. ${ }^{34}$ Ludwig Achim von Arnim's German novella, Isabella of Egypt, the First Young Love of Emperor Charles V (1812) made particular play with the traditions. The father of the eponymous Isabella, who was the king of the gypsies, is unjustly hanged as a thief. She reads his books of magic and comes across a ritual for raising a homunculus from a mandrake. She goes to the gibbet site where her father was hanged to gather one, sacrificing her pet dog to pull it out of the ground. In Britain, Harrison Ainsworth's popular novel, Rookwood (1834), which was set in 1737, also figures gypsies as well as the highwayman, Dick Turpin. In one passage, one of Turpin's accomplices sings a ballad about the mandrake that begins with 'The mandrake grows 'neith the gallows tree', with a subsequent verse explaining:

At the foot of the gibbet the mandrake springs,

Just where the creaking carcass swings;

Some have though it engendered

From the fat that drops from the bones of the dead;

Some have thought it a human thing;

But this is vain imagining.

Jacob Grimm's account of the alraun in his magnum opus, Teutonic Mythology (1835), further promoted the gallows mandrake from legend to myth, by suggesting that the plant was associated with the goddess, Aurinia, and that early Germanic wise women/diviners, known as the 
alruna, gave their name to the mandrake. It was sources such as this that inspired the unsettling vampire novel, Alraune (1911), by Heinz Ewes. It concerns an anthropologist named Frank Braun, who, on hearing of the legend of the gallows mandrake, convinces his maverick scientist uncle to recreate a homunculus by artificially inseminating a Berlin prostitute with the semen of a notorious hanged murderer. The result is a beautiful but deadly female vampire called Alraune. The story was made into several film adaptations over the next few decades. ${ }^{35}$

It is difficult to demonstrate any firm correlation between the decline of the gallows mandrake trade and changing execution practices and patterns, but there were some likely influences. The shift of execution sites to centralised urban locations and the decline of post-mortem display in the countryside would have, practically and notionally, reduced the association with the earthy human compost in which the mandrake was thought to grow. Mandrakes without gallows associations continued to be sold, however, as a herbal remedy and as an amulet for good luck, into the nineteenth and early twentieth centuries. The London folklorist, Edward Lovett, purchased a couple of specimens that had not been 'touched up', and recorded that people sometimes fixed one to the bedhead for good luck. In the early twentieth century, a vendor of what were purported to be mandrakes with humanoid forms sold them from his pitch in Petticoat Lane, London. He told his customers, 'I pulls 'em at midnight, and they screams 'orrible as they come out of the ground.' Penny slices of mandrake were also sold as a general cure-all. ${ }^{36}$

\section{The Last of the Executioners’ Perquisites}

As has already been noted, the scaffold or execution platform was a temporary construction. However, while it still stood, there was a brief opportunity to obtain part of the structure. By the mid-nineteenth century, the trade in fresh body parts was at an end across Europe, the control over the corpse having been wrested from the executioners, but in hanging countries, in particular, they still had a degree of control over the gallows and the tools of the trade, and people had long sought out pieces of the execution apparatus for medicine and magic.

Nails were widely prized in some places, for example. In 1776, a Swedish executioner, named Lars Hierpe, was prosecuted for lending the nails that had been driven into the head and hand of an executed thief to a farmer, named Jöns Persson, who used them to cure his livestock. 
Hierpe testified that he had taken the nails from the body, 'partly because of one Jöns Persson's wish, partly because of the old tale that such nails are useful for the horse-barterer to make the horses livelier' ${ }^{37}$ Thomas Browne, writing in the mid-seventeenth century, mentioned how 'for amulets against Agues we use the chips of Gallows and places of execution', and the late-eighteenth century antiquarian, Francis Grose, noted that pieces from the gibbet or gallows were placed in a bag and worn around the neck to cure or prevent ague. Earth from the scaffold graves of the executed was prized for its miraculous power in parts of Italy. The antiquarian, John Brand, recalled having seen, in 1746, bloodsoaked scaffold sawdust from the beheadings of the treasonous Jacobites, Lord Balmerino and the Earl of Kilmarnock, used to charm away some illness. Jacob Grimm referred to the belief that a spur made from a gibbet chain possessed magical potency. ${ }^{38}$

The most enduringly desired artefact from the execution site, and the one most controlled by the executioner, was the hanging rope. After all, it was, by custom, the hangman who paid for it from his fees. It had been much sought after for centuries for healing. Before the age of the guillotine and garrotte, the hanging rope was used in France and Spain as a cure for headaches by touching the temple with it, and pieces were kept in the pocket against toothache. In Transylvania, a piece of hangman's rope placed in the bed was thought to prolong the life of those near death. ${ }^{39}$ The rope, like criminal corpse body parts, was also thought to have non-medical magical properties. The inquisition tribunal records for sixteenth-century Spain contain numerous references to its use in love magic. One woman confessed before the tribunal 'that she used rope from a hanging and carried it with her to lure men's wills'. María Tausiet has observed 'the symbology of subjugation linked to death by asphyxiation and embodied in the hangman's noose, which had the ultimate control over another person's will'. ${ }^{40}$ In early modern Germany and in early nineteenth-century Molise, central Italy, it was thought to act as a talisman against gunshot. The most pervasive and enduring market for hanging rope through to the twentieth century was amongst gamblers of all levels of society, who prized it as a luck-bringer. ${ }^{41}$ As with body parts, the executioner had to contend with competition for this perquisite. In one early modern German instance, a robber, named Hörnlein, was prosecuted for having stolen a piece of rope from the gallows in broad daylight. ${ }^{42}$ There was no doubt a trade in fake pieces of rope as well. 
The rope was a prominent part of British folk medical and magical tradition, as it was the main hanging country in Western Europe during the nineteenth century. Just as people came to hangings to feel the touch of the hanged man's hand for swellings, so they also came to obtain a bit of the rope for the cure of ague, epilepsy and other ailments. One woman travelled fifteen miles to attend the hanging of the highwayman, Nicholas Mooney, in 1752, and so obtain a section of the rope. John Brand remembered attending a hanging at Newcastle later in the century and witnessing several men climb the gallows after the body had been cut down to obtain pieces of the cord that remained. ${ }^{43}$ On most occasions, access to the rope was carefully controlled by the hangman. A nineteenth-century Herefordshire woman, whose child suffered from scrofula, was advised to go to the next hanging at Hereford and request the hangman to pass the rope over his body and lash him with it. ${ }^{44}$ The most common practice was for the hangman to cut up the rope shortly after the execution and sell the pieces then and there. The rope that hanged Joseph Wall, who was executed in London for flogging a soldier to death in 1802, was sold for one shilling per inch. There was a lively trade at the execution of the murderer, Benjamin Ellison, at Bodmin gaol, Cornwall, in August 1845. The hangman, George Mitchell, charged a shilling a piece. Some months later, a surgeon at the local infirmary was treating a patient for an ulcerous wound on his back and found a little chintz bag around his neck. When he inquired what it contained, the patient replied that it was a bit of the rope from the recent hanging at Bodmin. The last time he had had a problem with ulcers on his back, the patient had buried a bit of the rope, and as the rope had rotted so his wound had healed. Now he kept a piece on him permanently. ${ }^{45}$ Any rope that did not sell on execution day could be traded subsequently, of course. A month after the notorious poisoner, William Palmer, was hanged at Stafford prison in June 1856, a Scottish newspaper reported that a man from Dudley, where the hangman George 'Throttler' Smith resided, had recently arrived in Lochmaben, Dumfriesshire, selling pieces of the rope at five shillings an inch. ${ }^{46}$

Just as the authorities made a concerted effort to stamp out the hanged man's touch during the mid-nineteenth century, so we find attempts to suppress the executioners' hempen perquisite. The rope used to hang William Dove in York, in 1856, was ordered to be placed in the coffin. Victor Hugo related that after the execution of Tapner in 1854, 'the dead man was cut down in an hour, and then it was a question 
who should steal the cord. The assistants threw it down, and each one claimed a piece; but the sheriff took it and threw it in the fire.' But people still came to collect the cinders. ${ }^{47}$ Things got decidedly awkward in British Guyana in 1871, when the colonial authorities forbade the hangman from selling the rope. He had been accustomed to charging between four pence and a shilling a piece. At the next execution in the colony, that of a wife murderer, the hangman protested at the loss of his perquisite by refusing to cut down the dangling corpse. ${ }^{48}$

The Vienna Scharfrichter, Heinrich Willenbacher, who executed a modest 36 people during his 24-year tenure during the mid-nineteenth century, reportedly pined for the old days when Austria had its headsmen and their noble skill with the sword. 'There was room for talent in those days,' he was apparently wont to lament. 'But now it is poor work. Rope, rope, nothing but rope! What's hanging, indeed?' $49 \mathrm{He}$ kept the official four-foot-long execution sword above his bed to remind him of better times, but it was rope that sustained his livelihood. Willenbacher was prosecuted in 1881 for quackery and abusing his position. ${ }^{50}$ During the prosecution of a recidivist thief, who was sentenced to 4 years' hard labour, his elderly mother gave testimony that she had tried everything to get her son to mend his criminal tendencies, including a visit to Willenbacher. He gave her what he claimed was a bit of the rope with which he had hanged Enrico Francesconi in December 1876. Francesconi, who was found guilty of the sensational robbery and murder of a postman, was the first to be hanged behind closed doors (by Willenbacher) in the Vienna jailhouse, following a law of $1873 .{ }^{51}$ Willenbacher instructed the old woman to place the rope under her son's pillow, and if that did not cure her son of his criminality, then he would draw blood from him with his executioner's sword. After hearing this testimony, the district court ordered Willenbacher's arrest. He pleaded clemency, saying that with so few executions to conduct in Austria, he lived in poverty with his six children. He was evidently pardoned and continued in the role of hangman until his death in 1886, when it was reported that, despite his penurious position, the money he made by selling the rope to 'superstitious people', apparently at ten shillings an inch, was charitably distributed amongst the poor. ${ }^{52}$

Where public hanging continued into the late nineteenth and early twentieth centuries, we find the continued resort to the hanging rope. This was mainly in Eastern Europe. In 1880, the Russian state executioner, a convict named Froloff, who had murdered his own family, made 
good money from selling his ropes, including those he used to hang a group of Nihilists who had assassinated Czar Alexander II. He bungled the job badly, with the rope around Timofey Mikhaylov's neck snapping twice before Froloff finally put the poor man out of his agony. Still, this was good news for the hangman, because it left him with more rope to sell. ${ }^{53} \mathrm{He}$ sold several dozen pieces on this occasion at three to five roubles. Young gamblers were the keenest purchasers, but there was clearly also a relic trade, with one report stating that strips of the hoods placed over the executed were sold to Nihilist supporters for a healthy profit. ${ }^{54}$ Following an execution in Bulgaria in 1915, it was reported that there was a crush inside and outside the prison due to people attempting to obtain pieces of the rope for luck and good health. ${ }^{55} \mathrm{~A}$ decade later, there were chaotic scenes after the public hanging of three Communists found guilty of blowing up St. Nedelya Church in Sofia. Petar Zadgorski, Marko Fridman and Georgi Koev were hanged separately by the country's official hangman, Hussein Jasara, an itinerant gypsy, who reaped a handsome profit selling pieces of the three ropes for good luck. For some, Jasara got his just deserts when he was killed in a fight in the gypsy quarter of Sofia in $1932 .{ }^{56}$

Where the sale of the rope was not expressly forbidden by the authorities, the end of public hanging did not necessarily mean an end to this hangman's privilege. When the Hungarian hangman, Michael Bali, retired in 1924 after 30 years' service, he had accumulated enough money to purchase a small estate near Budapest. Some of those funds came from his sale of pieces of the hanging rope. ${ }^{57}$ During his time in office, he had to fight hard and publicly to try and retain his perquisite. In 1912, Bali had a widely reported dispute with the public prosecutor of Temesvár (Timişoara in Romania). Shortly after he had conducted an execution behind the prison walls, Bali untied the rope and began to cut it up, intending, as usual, to auction the pieces to crowds waiting outside. The prosecutor, who was in attendance, ordered Bali to hand over the rope to him, as riotous scenes had recently taken place in similar circumstances following a hanging at Miskolez. A Vienna correspondent, observing a hanging around the same time, probably the same, reported on the crush to get a bit of rope, and that away from the hubbub 'elegant women in carriages' waited expectantly to purchase pieces. ${ }^{58}$ Bali refused, arguing that not only was it his perquisite by custom, but also his own property, as he had to purchase the hanging rope at his own 
expense. A policeman took the rope by force and Bali stated he would take legal action to recover it. ${ }^{59}$

\section{Money for Old Rope}

As already noted, in France, the Revolution had a considerable impact on the perquisites, status and medical practices of the bourreaux. The guillotine hit their income as they no longer had a supply of hanging rope to sell. Their Spanish brothers felt the same with the adoption of the garrotte. However, the power of the hanging rope lived on in both countries. The critic of popular errors, Jacques-Barthélemy Salgues, wrote in 1810 that the phrase 'avoir de la corde de pendu' ('to have the rope of the hanged') had become a popular proverb to mean having constant good luck. ${ }^{60}$ No wonder the desire for old rope continued. It was reported, in 1888, that the corde de pendu was still widely believed in and desired as a talisman in Bordeaux and the Gironde region, and in 1890 the folklorist, Paul Sebillot, compiled a long list of references to the ongoing potency of the rope in French, Belgian and Portuguese folklore. ${ }^{61}$

As well as the trade in very old pieces of French hanging rope, it could, of course, still be obtained from countries that continued to practise hanging long after France had given up the method. In 1874, the British and French press reported how a French businessman, who had visited Dublin a few years before, had taken the opportunity while there to purchase a piece of rope at the recent hanging of an Irish murderer conducted by William Calcraft. He apparently paid Calcraft five sovereigns for it, in the hope that it would bring good luck and prosperity to his family and business. The press recounted how the poor man experienced just the reverse. One of his children nearly died after 'playing hangman' with the rope. When he used the rope to seal a box of money on a business trip, he was robbed of its contents during the journey. In a state of despair, he later attempted to hang himself with the rope, only to be cut down by his wife before he died. ${ }^{62}$ When, in 1883, the English press reported that 21 of the hanging ropes owned by the recently deceased British executioner, William Marwood, were to be sold at auction in London, one newspaper suggested that 'it is only to be feared that they have come, in the first place, to the wrong market'. There was huge demand in Paris for hanging rope as a lucky charm, it reported, 
noting that French gamblers and the superstitious had to rely on suicides for pieces. ${ }^{63}$

In the 1880s, it was apparently not unusual for Parisian medical students to sell bits of the rope that were still attached around the necks of suicides brought into the hospitals. One report tells of a piece given to a chemist's assistant in Amiens, who then went on to win one hundred thousand francs in a lottery. ${ }^{64}$ There are examples from nineteenthcentury Sweden of suicide rope also being used for curing sores and taming horses. ${ }^{65}$ In 1923, in the village of Klimontowice, in the region of Galicia, which now straddles parts of modern Poland and Ukraine, a farm labourer, named Jan Pietraszek, was found hanging in his barn. A local bailiff confessed that he and Pietraszek had been on a drinking spree and, on returning to the latter's home, the labourer died of a heart attack. The bailiff, knowing the value of the hanging rope, hatched a plan whereby he got a cord and strung up Pietraszek's corpse to make it look like a suicide. His intention was then to obtain the rope and sell it in pieces. ${ }^{66}$

What of the influence of those who made hanging ropes? In early modern Brittany, the ostracism of the rope-makers was apparently unusually marked, with them being classed alongside outcast trades, such as skinners, knackers and hangmen. They turned their situation to advantage by selling charms and talismans. ${ }^{67}$ Although only a very tiny percentage of the rope-making business was concerned with hanging rope, the association was strong, with jokes about the rope-makers' enthusiasm for this macabre aspect of their trade. There was the much-repeated story of the rope manufacturer, who complained, 'what makes it hard on rope-makers is that that least fifty men die daily of natural causes who ought to be hanged.' Much humour arose during the proceedings for bankruptcy against the English hangman, Thomas Henry Scott, at Halifax County Court in 1899. His rope-making business had failed, and government requests for his hanging services had dried up. Scott referred to himself in court as being in the 'rope trade', which was the cue for humorous exchanges as to which of his occupations he was referring. ${ }^{68}$ As with hangmen who ended up being executed for murder, so reports about rope-makers who committed suicide by hanging themselves proved too irresistible to pass up without comment. Regarding a rope-maker who hanged himself in Stamford, for example, it was observed that it was 'a grim compliment to his peculiar calling'. ${ }^{69}$ Some rope-makers were happy to exploit their association with death, though. 
Prior to the hanging of William Dove at York, the locally commissioned rope-maker entered into a deal with a public house to display the cord, thereby attracting a large crowd of punters wishing to touch it-and hopefully buy more beer. The rope that put an end to William Palmer in the same year was commissioned from a rope-maker, named Coates, who was also a porter at Stafford station. He made thirty yards of it, with the help of other fellow station employees. The required length for the hanging was, of course, far less than thirty yards. Coates had seen a good money-making opportunity. He cut up the excess into 2- or 3-in pieces and hawked them as the rope that hanged Palmer, selling them for up to half a crown around Stafford. ${ }^{70}$

During the second half of the nineteenth century, one of the main suppliers of gallows ropes across America was the Edwin H. Fitler cordage works at Bridesburg, Philadelphia. Its employee, Godfrey Boger, who died in 1911, specialised in the fabrication of gallows ropes for the company, making his first one for a hanging in 1854. Only one of his ropes ever broke. Hemp of the finest quality was required, and this meant purchasing it from Italy. Boger never witnessed an execution, despite many offers, and was unconcerned by the notion that gallows rope-makers were destined to die tragically. By custom, though, the company never charged for execution ropes, only for the cost of delivery, suggesting some sensitivity to the beliefs surrounding their doleful trade. Other rope-makers abided by no such custom, with one charging five dollars for ropes with a ready-made noose. ${ }^{71}$ In 1909, Sheriff John Schum of York County, Pennsylvania, reported having trouble finding a gallows rope in anticipation of hanging the convicted murderer, George Govogovitch. He put down his difficulty to the superstition amongst rope-makers that making ropes for hangings brought bad luck. He recalled that, some years before, when sourcing a hanging rope, several cordage companies had gone out of business, and their fate was attributed to them having branched into the gallows trade. ${ }^{72}$

\section{Memento or Talisman? An American Perspective}

After scouring the folklore archives, the eminent American folklorist, Wayland Hand, was led to conclude that the use of the hanging rope as a cure was rare in America, and largely limited to Anglo-Americans and German-Americans in Pennsylvania and Ohio. Use of parts of the 
scaffold was equally scarce. He suggested that the lack of data on both traditions was a result of the 'rarity of hanging at a time when folklorists, local historians, and other antiquarians came on the scene to report such happenings'. ${ }^{73}$ Public hangings had largely ended in the north-eastern states by the mid-nineteenth century, and most of the southern states by the end of the century. Arkansas continued to conduct public hangings for rapists into the early twentieth century, while Georgia and Mississippi briefly re-authorised public hanging around 1900, but as states turned to the electric chair, the noose was increasingly abandoned. Kentucky was the last to continue public hangings into the 1930s. ${ }^{74}$ The abolition of public execution was not straightforward. Numerous hangings continued in semi-public spaces, or in jail yards, where the number of invited guests seems to have been quite considerable sometimes. Neither was solemn, respectful behaviour guaranteed, with some reports describing the selected witnesses behaving like a 'mob'. ${ }^{75}$ So there were opportunities to obtain hanging rope into the early twentieth century, when folklore collecting was thriving.

As Hand suggested, searches of other sources, such as diaries, police records and 'rare local histories', might prove helpful to clarifying the practices of execution healing and magic. The Online Archive of American Folk Medicine, for example, reveals that the curative hanging rope tradition for fits and warts was also known in Maryland and Indiana. ${ }^{76}$ The digitisation of newspaper reports helps the research into this tradition. Such reports confirm that the belief and usage of the gallows rope in popular medicine and magic was much more widespread than the folklore sources suggest. This is not really surprising, considering how widespread the demand for rope was in Europe at the same time.

The St. Louis Republican noted, in 1882, that if all the hangman's rope were taken from the pockets of the superstitious St. Louisians, they would form a rope of considerable length'. It was considered a 'cure for rheumatism, consumption, heart disease, apoplexy, and everything else' and several people in the town were selling pieces. ${ }^{77}$ After the execution of the murderer, Jack Reynolds, in New York in 1870, an elderly lady visited The Tombs (the New York Halls of Justice and House of Detention) and asked the deputy warder for a few inches of the hanging rope to cure her son, who suffered from the King's Evil. The rope had, in fact, been kept by the carpenter who built the scaffold, so a medical 
man present promised to obtain a piece for her, went into the kitchen and chopped a bit of clothes' line and gave it to her, leaving the woman satisfied. ${ }^{78}$ Just after the hanging of William Finchum for fratricide, in Harrisonburg, Virginia, in December 1887 (Virginia had been hanging before select private audiences since 1879), 'the rope was cut into small bits, and distributed to those of the spectators who wished it. Some took it from curiosity, and other to keep, on account of a superstition that it will keep off diseases, fits, spells, \& c. ${ }^{79}$ At the New Orleans murder trial of Patrick Egan, in December 1885, it transpired that Egan, a well-known hoodlum, carried in his pocket a piece of hangman's rope for good luck. He had obtained it while attending the prison hangings of Victor Eloi and Kendrick Holland, condemned for murdering their wives. This was shortly before Egan murdered George Blake. Egan was sentenced to death but was reprieved by the Supreme Court on a technicality. A new trial was called, but the case was now considerably weakened, leaving the press to conclude that 'the luck of the hangman's rope has saved his neck' ${ }^{80}$

A number of American reports noted the desire of execution crowds to obtain pieces of the gallows as mementos. The gathering of souvenirs at public executions was common enough across Europe as well. In January 1879, at a double hanging in the semi-public space of Indianapolis jail yard, the sheriff employed 125 men to control the crowd. However, 'while they were still hanging the crowd of invited guests began cutting pieces from the scaffold, and as soon as they were cut down there was a scramble for pieces of the rope.' ${ }^{81}$ In March 1902, preparations for the hanging of Charles Woodward, in Casper, Wyoming, included crowd-control measures, with the anticipation that 'memento fiends will be on hand in large numbers to secure a piece of the rope and pieces of the scaffold'. ${ }^{82}$ Following the hanging of Richard Mkwayne in York, Pennsylvania, in 1908, 'the rope was hacked into bits for souvenirs. Some of these changed hands at as much as $\$ 2$ a piece. ${ }^{83}$ There clearly was a trade in obtaining the rope for public display. In 1893, one journalist explained how hangmen often sold off their ropes, or pieces of it, to 'dime museum managers'. A month after the execution, in November 1887, of the four Haymarket 'anarchists', condemned to death after dynamite was thrown at police during a labour demonstration in Chicago, several dime museums around the country exhibited uncut ropes that were purported to be those that hanged the men. This claim 
was made, despite the ropes having been cut into pieces just after the hanging and sold as per usual. ${ }^{84}$

The lynching of African-Americans led to the horrific free-for-all collection of body parts that has been described in terms of ritualistic sacrificial murder. ${ }^{85}$ In 1906, a lynch mob took Nease Gillespie, John Gillespie and Jack Dillingham from Salisbury jail in North Carolina and hanged them. It was reported shortly after that 'thousands of people visited the scene of the lynching today. Many cut off fingers, ears, and other portions of the dead bodies, and carried them away as souvenirs. ${ }^{86}$ As well as hangings and lynchings, there are numerous reports during the American Civil War of soldiers taking body parts of their dead foes for trophies and souvenirs. Accusations of such activity were particularly levelled at Confederate soldiers, and despite the obvious propaganda aspects of such stories, the taking of body parts clearly happened. Local slaves reported to a Union army surgeon that Confederate soldiers had dug up soldiers' graves to make rings from the bones and drinking cups from skull tops. ${ }^{87}$

There was a tendency in the American press to assume that EuropeanAmericans were less 'superstitious' than their European cousins, and hence, perhaps, the regular reporting of hanging rope selling as part of the souvenir trade. How do we know, though, that these items were desired solely as macabre souvenirs? How many of these 'memento fiends' were actually acquiring them for magical and medical means? The Civil War was only a few decades on from the German reports of people taking fingers and other parts from the criminal corpses displayed on the wheel, and there were many ethnic German soldiers in the Civil War armies. ${ }^{88}$ In England, the tradition of cramp bones kept in the pocket or under the pillow was widespread. While in most English folklore sources cramp bones were from the patella or knucklebone of a sheep or hare, one antiquarian noted in the early nineteenth century that he had 'heard that some of strong nerve, resolving to prevent the approach of so unwelcome an assailant as the cramp, have been known so temerarious as to wear the more potent spell of a human patella. ${ }^{\prime} 99$ We also need to bear in mind that mementos and souvenirs could accrue amulet-like power as they passed through different owners' hands over the years. Likewise, a piece of rope purchased for luck could, decades later, have no meaning other than as a historic curiosity, the motivation of its original owner completely lost to history. 


\section{Notes}

1. See Spierenburg, The Spectacle of Suffering, ch. 3.

2. Steve Poole, "For the benefit of example": Crime scene executions in England, 1720-1830', in Richard Ward (ed.) A Global History of Execution and the Criminal Corpse (Basingstoke, 2015), pp. 71-102. For examples in Scotland, see Rachel Bennett, Capital Punishment and the Criminal Corpse in Scotland 1740 to 1834, forthcoming.

3. Jorris Coolen, 'Places of justice and awe: the topography of gibbets and gallows in medieval and early modern north-western and Central Europe' World Archaeology 45 (2014) 767.

4. Evans, Rituals of Retribution, pp. 225-226.

5. The Monthly Magazine, 47 (1819) 509.

6. Sarah Tarlow, Hung in Chains: The Golden and Ghoulish Age of the Gibbet in Britain (Basingstoke, 2016); Zoe Dyndor, 'Gibbets in the Landscape: Locating the Criminal Corpse in Mid-Eighteenth Century England', in Ward (ed.), Global History of Execution, pp.102-126; Bennett, Capital Punishment and the Criminal Corpse in Scotland; Coolen, 'Places of justice and awe', 762-779; L. Meurkens, 'The Late Medieval/Early Modern Reuse of Prehistoric Barrows as Execution Sites in the Southern Part of the Netherlands', Journal of Archaeology in the Low Countries 2 (2010) 5-29; Nicola Whyte, 'The deviant dead in the Norfolk landscape', Landscapes 4 (2003), 24-39; Nicola Whyte, 'The after-life of barrows: prehistoric monuments in the Norfolk landscape', Landscape History 25 (2003) 5-16.

7. John Field, A History of English Field Names (1993), pp. 237-239; Johannes A. Mol, 'Gallows in Late Medieval Frisia', in Rolf H. Bremmer Jr., Stephen Laker and Oebele Vries (ed.), Advances in Old Frisian Philology (Amsterdam, 2007), pp. 276-277.

8. F. Hancock, Wifela's Combe: A history of the Parish of Wiveliscombe (Taunton, 1911), p. 253; Taunton Courier, 2 November 1921. See more generally, Owen Davies, The Haunted: A Social History of Ghosts (Basingstoke, 2007), pp. 51-54.

9. Ethel H. Rudkin, 'Lincolnshire Folklore', Folklore 44 (1933) 209.

10. Henry Swainson Cowper, Hawkshead (London, 1899), p. 326; Theresa M. Kelley, Wordsworth's Revisionary Aesthetics (Cambridge, 1988), p. 120; A. Craig Gibson, 'The Lakeland of Lancashire: Hawkshead Town, Church and School', Transactions of the Historic Society of Lancashire and Cheshire N.S., 5 (1865) 147.

11. London Morning Penny Post, 28 August 1751.

12. 'Spectre-Dogs', Chambers' Book of Days (Edinburgh, 1864), pp. 433-434. 
13. Theo Brown, 'The Black Dog' Folklore 69 (1958) 176, 185; Davies, The Haunted, p. 37; Bob Trubshaw, Explore Phantom Black Dogs (Loughborough, 2005); Mark Norman, Black Dog Folklore (London, 2016).

14. Thomas Rudge, The History of the County of Gloucester: Compressed (Gloucester, 1803), Vol. 1, p. 239; Samuel Rudder, A New History of Gloucestershire (Cirencester, 1779), p. 606.

15. Thomas Rossell Potter, The History and Antiquities of Charnwood Forest (London, 1842), p. 179.

16. 'Hangman's Stone', Manchester Weekly Times, 27 May 1898; O.G.S. Crawford, 'Hangman's Stones', Notes \& Queries 12 Series, xi (1922) 50-52.

17. Malcolm Jones 'The Hangman's Stone and the Unwonted Fruit: Two Emblems of Folkloric Origin', Emblematica, 5 (1991), 287-299; Arnoud S.Q. Visser, Johannes Sambucus and the Learned Image: The Use of the Emblem in Late-Renaissance Humanism (Leiden, 2005), p. xxiv.

18. Geoffrey Whitney, A Choice of Emblemes (Leiden, 1586), p. 41.

19. Peter King, Crime, Justice, and Discretion in England, 1740-1820 (Oxford, 2000), p. 314, n. 51. See also, John Rule, 'The Manifold Causes of Rural Crime: Sheep-Stealing in England, c. 1740-1840', in John Rule (ed.), Outside the Law (Exeter, 1982), pp. 102-129.

20. Thomas Fuller, The History of the Worthies of England (London, 1662), p. 247.

21. Jacqueline Simpson, 'Seeking the Lore of the Land', Folklore 119 (2008) 133.

22. Alexandra Walsham, Providence in Early Modern England (Oxford, 1999), pp. 97-98; Alexandra Walsham, The Reformation of the Landscape: Religion, Identity, and Memory in Early Modern Britain and Ireland (Oxford, 2011), p. 499.

23. Charles Brewster Randolph, 'The Mandragora of the Ancients in FolkLore and Medicine', Proceedings of the American Academy of Arts and Science 40 (1905) 487-532; R.K. Harrison, 'The Mandrake and the Ancient World', The Evangelical Quarterly 28 (1956) 87-92; Jeannine E. Talley, 'Runes, Mandrakes, and Gallows', in Gerald James Larson, C. Scott Littleton and Jaan Puhvel (eds), Myth in Indo-European Antiquity (Berkeley, 1974), pp. 157-168; Marie-Françoise Notz, 'La Mandragore merveilleuse', Cabiers Ethnologiques 14 (1992) 129-142; Anne Van Arsdall, Helmut W. Klug and Paul Blanz, 'The Mandrake Plant and its Legend: A New Perspective', in Peter Bierbaumer and Helmut W. Klug (eds), Old Names-New Growth: Proceedings of the 2nd ASPNS Conference (Frankfurt, 2009), pp. 285-347.

24. Van Arsdall, Klug and Blanz, 'The Mandrake Plant', p. 333. 
25. Laurent Catelan, Rare et curieux discours de la plante Mandragore (Paris 1638), pp. 3-4.

26. Randolph, 'The Mandragora', 495.

27. Jennifer Evans, Aphrodisiacs, Fertility and Medicine in Early Modern England (Woodbridge 2014), p. 178.

28. John Gerard, The Herball or Generall Historie of Plantes (London, 1633), p. 351 .

29. Thomas Browne, Pseudoxia Epidemica (London, 1658), Book 2, p. 107.

30. William R. Newman, 'The Homunculus and the Mandrake: Art Aiding Nature Versus Art Faking Nature', in Jessica Riskin (ed.), Genesis Redux: Essays in the History and Philosophy of Artificial Life (Chicago, 2007), pp. 123-128; William R. Newman, Promethean Ambitions: Alchemy and the Quest to Perfect Nature (...), pp. 208-217; Frederick J. Simoons, Plants of Life, Plants of Death (Wisconsin, 1998), pp. 121-127.

31. Harrington, Faithful Executioner, p. 209.

32. Johann Georg Keyssler, Antiquitates selectae septentrionales et Celticae (Hanover, 1720), pp. 507-509.

33. Secrets merveilleux de la magie naturelle et cabalistique du Petit Albert (Lyon, 1752), pp. 166-168.

34. Thierry Zarcone, "The Myth of the Mandrake, the "Plant-Human", Diogenes 52 (2005) 115-129.

35. Rob Craig, It Came from 1957: A Critical Guide to the Year's Science Fiction, Fantasy and Horror Films (Jefferson, 2013), pp. 51-54.

36. Ruth A. Firor, Folkways in Thomas Hardy (Philadelphia, 1931), pp. 114-115; Edward Lovett, Magic in Modern London (Croydon, 1925), p. 74; Nottingham Evening Post, 12 June 1920.

37. Van Gent, Magic, Body and the Self, pp. 155-156.

38. Thomas Browne, Pseudodoxia epidemica, or, Enquiries into very many received tenents and commonly presumed truths (London, 1646), p. 272; Francis Grose, A provincial glossary, with a collection of local proverbs, and popular superstitions (London, 1787), p. 57; Per Binde, Bodies of Vital Matter: Notions of Life Force and Transcendence in Traditional Southern Italy (Gothenburg, 1999), p. 126; Brand, Observations, p. 583; Jacob Grimm, Teutonic Mythology, trans. James Steven Stallybrass (Cambridge [1883], 2012), vol. 3, p. 1138.

39. Strack, The Jew and Human Sacrifice, p. 75.

40. Tausiet, Urban Magic, pp. 93, 94; Víctor Lis Quibén, La medicina popular en Galicia (Pontevedra, 1949), p. 273.

41. Binde, Bodies of Vital Matter, p. 126; W.L. Hildburgh, 'Notes on some Flemish Amulets and Beliefs', Folklore 19 (1908) 204.

42. Harrington, Faithful Executioner, p. 187.

43. Brand, Observations, p. 583. 
44. Ella M. Leather, 'Notes on English Folklore: Herefordshire' Folklore 27 (1916) 415.

45. Frederick Printer Miller, Saint Pancras Past and Present: Being Historical, Traditional, and General Notes of the Parish, etc. (London, 1874), p. 42; Yorkshire Gazette, 13 September 1845; South Australian Register, 11 April 1846.

46. Stirling Observer, 3 July 1856.

47. Davies, Murder, Magic, Madness, p. 162.

48. Georgetown Gazette, reprinted in the Bradford Daily Telegraph, 28 June 1871 .

49. Illustrated Police News, 3 April 1886.

50. Nene Freie Presse, 13 February 1881; Welt Blatt, 16 February 1881.

51. Harald Seyrl, 'Todesstrage in Österreich (1876-1950)', in Maria Loredana Idomir, Matthias Keuschnigg, Michael Platzer (eds), Vienna Conference on the Abolition of the Death Penalty November 2-13, 2011: Working Together towards the Universal Abolition of the Death Penalty (Vienna, 2011), pp. 28-29; Anna Ehrlich, Hexen - Mörder - Henker: Die Kriminalgeschichte Österreichs (Vienna, 2006).

52. Illustrated Police News, 3 April 1886.

53. London Telegraph, reprinted in Derby Daily Telegraph, 30 March 1880; William Dixon Bancroft, McKinley, Garfield, Lincoln; their livestheir deeds - their deaths - with a record of notable assassinations and a history of anarchy (Chicago, 1901), p. 511.

54. Western Daily Press, 2 May 1881.

55. The Near East, 9 (1915) 406.

56. Widely reported in the press, though not always accurately. See, for example, San Antonio Light, 9 August 1925; Pittsburgh Press, 18 October 1932.

57. Cornell Daily Sun, 26 September 1924.

58. Western Daily Press, 15 August 1911.

59. Colonist, 15 August 1912.

60. Jacques-Barthélemy Salgues, Des erreurs et des préjugés répendus dans la société (Paris, 1910), p. 404.

61. Camille de Mensignac, Notice sur les superstitions, dictons, proverbes, devinettes et chansons populaires du département de la Gironde (1888), p. 130; Paul Sebillot, 'Les Pendus', Revue des Traditions Populaires 5 (1890) 592-594.

62. See, for example, Western Gazette, 24 April 1874.

63. Gloucester Citizen, 11 October 1883.

64. Illustrated Police News, 16 May 1885.

65. Nordiska Museet Arkivet, Botemedel 3, 23499, 23503, 28905, 26013.

66. Gloucester Echo, 7 November 1923. 
67. Anne Plumptre, A Narrative of Three Years' Residence in France (London, 1810), vol. 3, p. 233.

68. North Wales Times, 2 April 1898; South Wales Echo, 21 June 1899.

69. Portsmouth Evening News, 24 May 1883.

70. Davies, Murder, Magic, Madness, p. 153; Illustrated Life and Career of William Palmer (London, 1856), p. 113.

71. New Castle News, 28 June 1911; Chris Woodyard, 'Enough Rope: The Hangman's Rope in the Press', http://hauntedohiobooks.com/news/ enough-rope-the-hangmans-rope-in-the-press/.

72. Trenton Evening Times, 12 March 1909. Govogovitch's death sentence was commuted on a technicality.

73. Hand, Magical Medicine, pp. 71-72, 76.

74. Stuart Banner, Death Penalty: An American History (Cambridge, MA, 2002), pp. 154-156.

75. Annulla Linders, 'The Execution Spectacle and State Legitimacy: The Changing Nature of the American Execution Audience, 1833-1937', Law and Society Review 36 (2002), 607-656, esp. 627.

76. https://unitproj.library.ucla.edu/dlib/folkmed/index.html.

77. Reprinted in the Wellsville Allegany County Democrat, 14 June 1882.

78. Boston Journal, 23 June 1870.

79. Rockingham Register, 5 January 1888.

80. New York Times, reprinted in the Dundee Courier, 24 December 1885.

81. New York Herald, 30 January 1879.

82. Denver Post, 23 March 1902.

83. Trenton Evening Times, 12 March 1909.

84. Reno Evening Gazette, 12 July 1893.

85. See Amy Louise Wood, Lynching and Spectacle: Witnessing Racial Violence in America, 1890-1940 (2011); Orlando Patterson, 'Rituals of Blood: Sacrificial Murders in the Postbellum South', Journal of Blacks in Higher Education 23 (1999) 123-127.

86. New York Times, 8 August 1906.

87. Simon Harrison, 'Bones in the rebel lady's boudoir: Ethnology, race and trophy-hunting in the American Civil War', Journal of Material Culture 15 (2010) 385-401; Simon Harrison, Dark Trophies: Hunting and the Enemy Body in Modern War (New York, 2014), pp. 93-117.

88. See, for example, Walter D. Kamphoefner and Wolfgang Helbich (ed.), Germans in the Civil War: The Letters They Wrote Home, trans. Susan Carter Vogel (Chapel Hill, 2006).

89. Roud, Superstitions, p. 119; Edward Moor, Suffolk Words and Phrases: Or, An Attempt to Collect the Lingual Localisms of that County (London, 1823), p. 90. 
Open Access This chapter is licensed under the terms of the Creative Commons Attribution 4.0 International License (http://creativecommons.org/licenses/by/4.0/), which permits use, sharing, adaptation, distribution and reproduction in any medium or format, as long as you give appropriate credit to the original author(s) and the source, provide a link to the Creative Commons license and indicate if changes were made.

The images or other third party material in this chapter are included in the chapter's Creative Commons license, unless indicated otherwise in a credit line to the material. If material is not included in the chapter's Creative Commons license and your intended use is not permitted by statutory regulation or exceeds the permitted use, you will need to obtain permission directly from the copyright holder.

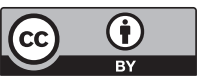

